Cinémas

Revue d'études cinématographiques

Journal of Film Studies

\title{
Teaching Quebec Film. Reflections of an American Academic
}

\section{Joseph I. Donohoe}

Volume 7, numéro 3, printemps 1997

Cinéma québécois et États-Unis

URI : https://id.erudit.org/iderudit/1000954ar

DOI : https://doi.org/10.7202/1000954ar

Aller au sommaire du numéro

Éditeur(s)

Cinémas

ISSN

1181-6945 (imprimé)

1705-6500 (numérique)

Découvrir la revue

Citer cet article

Donohoe, J. I. (1997). Teaching Quebec Film. Reflections of an American Academic. Cinémas, 7(3), 159-177. https://doi.org/10.7202/1000954ar

\section{Résumé de l'article}

Après avoir fait état des origines de son intérêt pour le cinéma québécois, l'auteur aborde plusieurs films qu'il a utilisés au cours des années dans ses classes d'étudiantes inscrit(e)s au premier cycle (Mon oncle Antoine, Pour la suite du monde et Sonatine) selon les points de vue à la fois de son intérêt personnel, comme enseignant et de leur réception auprès de ses étudiants. En conclusion, il développe un argument en faveur de la « transparence culturelle » des films destinés au marché international 


\title{
Teaching Quebec Film. Reflections of an American Academic
}

\author{
Joseph I. Donohoe, Jr.
}

\begin{abstract}
RÉSUMÉ
Après avoir fait état des origines de son intérêt pour le cinéma québécois, l'auteur aborde plusieurs films qu’il a utilisés au cours des années dans ses classes d'étudiant(e)s inscrit(e)s au premier cycle (Mon oncle Antoine, Pour la suite $d u$ monde et Sonatine) selon les points de vue à la fois de son intérêt personnel, comme enseignant et de leur réception auprès de ses étudiants. En conclusion, il développe un argument en faveur de la "transparence culturelle " des films destinés au marché international.
\end{abstract}

\section{ABSTRACT}

After recounting the origins of his interest in Quebec cinema, the author discusses several of the films which he has utilized over the years in his undergraduate classes (Mon oncle Antoine, Pour la suite du monde and Sonatine) from the points of view both of what they mean to him, how he teaches them and how they have been received by his students. In conclusion, he presents an argument in favor of the "cultural transparency" of films destined for the world market.

Happily, in retrospect, although it was then commonly looked upon as a piece of bad luck by myself and my fellow students, the high school which I attended in Philadelphia in the mid-fifties, La Salle College High School, shared a campus with a small liberal arts college also called La Salle. Among the consequences of the rich intellectual climate for high school students arising from this arrangement was - other than more difficult 
classes - my precocious taste for foreign cinema, especially French Cinema - probably because both institutions were owned and staffed by the Frères des écoles chrétiennes. Taking advantage of opportunities primarily intended for the student body of the College, I began, as a teenager, watching and discussing films like: La Règle du jeu (Renoir, 1939), Le Journal d'un curé de campagne (Bresson, 1950), Orphée (Cocteau, 1950) and Les Visiteurs du soir (Carné, 1942), along with more frivolous things like Fanfan la tulipe (Christian-Jaque, 1952) or Du rififi chez les hommes (Dassin, 1955). Since I attended La Salle College after high school, my early informal film education extended to about eight years and I learned among other things - something most American film viewers never learn - to accept en douceur the subtitles at the bottom of the screen.

Toward the end of the decade of the fifties, my education took an additional twist when La Salle - the Christian Brothers having connections there - sent me on scholarship to Quebec city in order to improve my French. My impression of Duplessis' Quebec was that of an agreeably quaint place which, by comparison with my native Philadelphia, seemed caught in a "time warp." I recall, for example, that when a group of foreign students, myself among them, approached the administration at Laval University - then headed by Monseigneur Parent - and requested the use of a room for a soirée dansante, it was explained to us that this was impossible since the Archbishop frowned on dancing in public! Fortunately, the Tennis Club of Quebec came to our rescue. I also remember, vividly, attending Sunday mass in a nearby church and hearing, to my great surprise, the pastor speak long and ardently about the sort of clothing women should and should not wear outside of the home. "Mesdames, il ne faut pas porter des vêtements suggestifs!" is a phrase which on occasion still rings in my ears. (If the poor man had only realized where it was all going!) Much later, I came to realize that the Church in Quebec was not terribly enthusiastic about cinema either, except under carefully controlled conditions. This probably explains why, my passion for film and the French language notwithstanding, I do not recall having encountered a single québécois film during my first visit. It was, in 
fact, only much later, after the completion of doctoral studies in French literature, and having begun work on a regular basis in the profession, that I would rediscover Quebec and finally encounter its by then emerging cinema.

Almost three decades after my initial visit as a student, I was asked by the CIC (a consortium of twelve leading universities of the American Mid-West) to act as Director of its Summer French Language Program in Quebec City. Accordingly, during the summers of 1983 and 1984, I lived in an apartment on Saint-Denis street, in the shadow of the Citadel, while I began to reacquaint myself with a new and dynamic Quebec which, during the Quiet Revolution, had made giant strides in all directions, including cinema. On my return to Michigan State University - I had previously taught at the University of Syracuse - I agreed to take over the lone class in Quebec Studies from the only colleague then working in that area and who was about to retire. Since I had maintained my interest in cinema, and was already teaching French film in the Department of Romance Languages, it was inevitable that I would begin to slip an occasional québécois film into my undergraduate classes on Quebec Studies or French film. It was on that basis, film by film, with the simple goal of sharing them with my students, that I was able to acquaint myself with the rapidly expanding repertory of films made by Quebec directors. Some of my early favorites, after I had discovered them on the list of "The Ten Best Canadian Films" compiled at the Toronto Film Festival in 1984, were Claude Jutra's Mon oncle Antoine (1971) and Pierre Perrault and Michel Brault's Pour la suite du monde (1963). A third film, Lanctôt's Sonatine (1983), I would discover on my own, some time later. Although, over time, I have introduced any number of other Quebec films into my various classes, the three mentioned above are the ones I have shown most often and with the most success to my students, and for that reason are the ones I have chosen to discuss here.

\section{Mon oncle Antoine}

When I first encountered the film, I found there was something typically québécois about Mon oncle Antoine, with its de- 


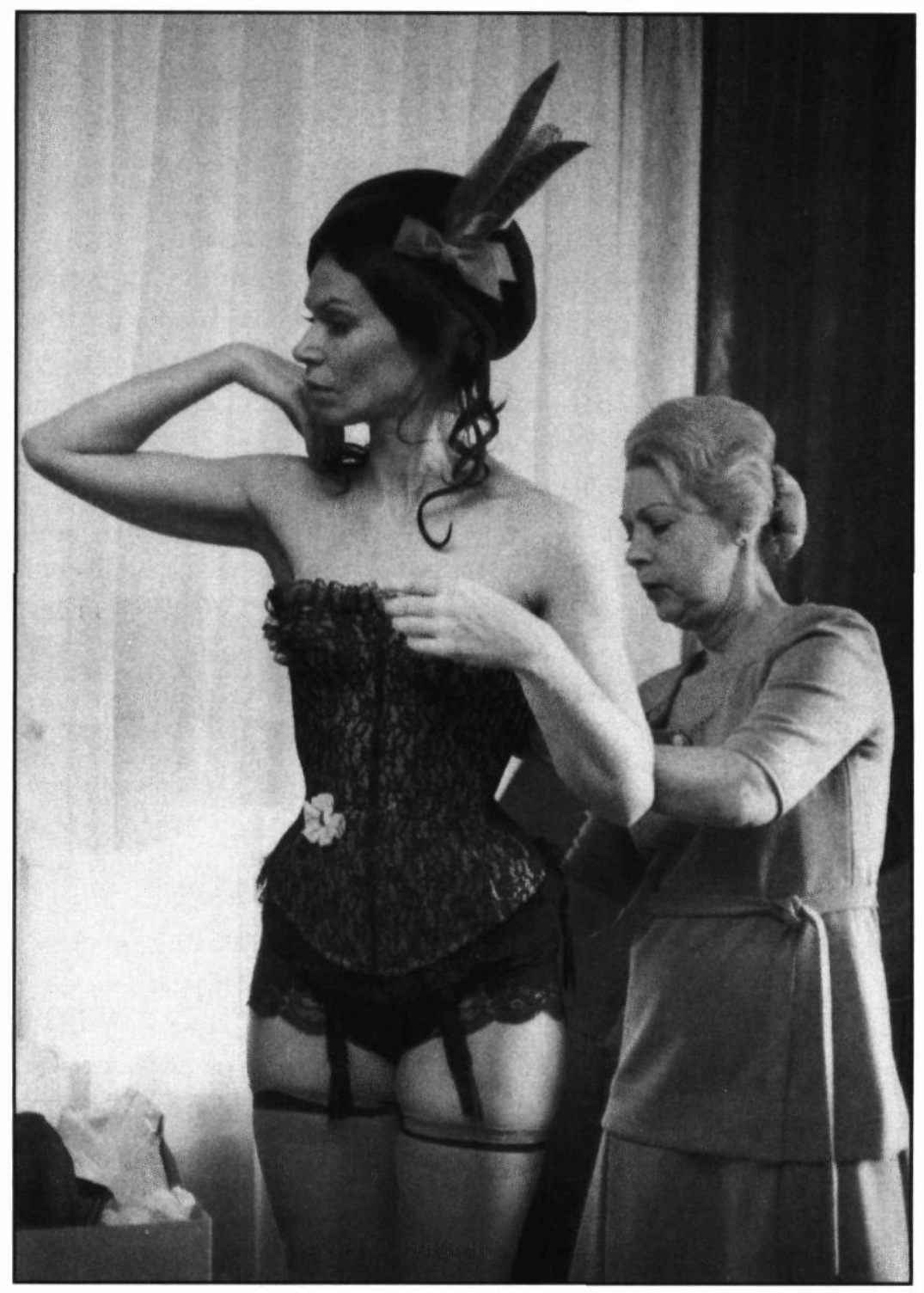

Mon oncle Antoine de Claude Jutra (1971) Collection ONF

liberate pace, diffuse narrative structure and allusions to the unsalutary presence of the English - elements which, I thought, added texture and interest to the story. I was therefore caught by 
surprise, when at a 1984 conference on Quebec Film in East Lansing, an American cinematographer cited dozens of departures from the Hollywood filmmaking canon in Mon oncle Antoine, and opined on the resulting difficulty of the film for an American audience. ' It occurred to me thereafter, as I watched my own students, that Mon oncle Antoine was for them, to some extent, a "closed" film, not because there were no attaching characters but because the film did not seem sufficiently to mythicize and thereby universalize the experience of those characters. What appeared on the screen was perhaps too explicit a representation of the particularity of Quebec's situation. Because the combination of stylistic and cultural obstacles caused difficulties for my Hollywood-trained student viewers, I eventually decided to provide them with background information on precultural revolution Quebec, in advance of screening the film. Only when they had become acquainted with Quebec's long and frustrating quest for national identity and control of its destiny, did the various characters and the apparently disparate strands of narrative in Mon oncle Antoine begin to coalesce for them into a meaningful whole.

Uncle Antoine, himself, at a certain point, was no longer simply a man who had deceived himself and others about who he was, he became as well a metaphor of the conservative past, of centuries of repression and ultimately of the Province's colonialized psyche. Seen in this perspective, students were soon able to correlate his experience with the seemingly disconnected turmoil of Jos Poulin, a man of the present (the forties in the film) and the disabused clairvoyance of Benoît who appears to belong to another time, perhaps to the future.

Jos, rather than hiding submissiveness behind mauvaise foi, as did Antoine, rebels openly, if ineffectually, against the tyranny of English bosses in a desperate effort to recover his self-respect. Self-respect, it turns out, for the average Québécois of the forties, is both elusive and costly, and Jos is forced to travel far from his family in order to replace the job he abandoned in the asbestos mines. The poignancy of the unwanted separation, mirrored in the rugged tenderness of Jos' face as he takes leave of his wife, is heightened during his absence by the death of their eldest son. 
An event which, by virtue of the isolation of the rural home and the unavailability of medical care, seems further to underscore the corrosive presence of the English-dominated social order. Gazing at the body of the dead child in the last frames of the film, there is sadness and realization in the eyes of Jos but nothing else, not even a flicker of the anger that might presage an eventual will to act.

Having situated the two other principals, students tend to find their relationship with the Benoît character transparent. Unlike the other two whose passivity confounds them, they admire in the young man an irreverent enemy of appearances and recognize that his vitality and awareness point to a new day for Quebec. Benoît, they realize, unlike his elders, will not be content to remain for long the victim - either passive or rebellious - of English bosses or Church authority. He represents rather the promise and direction of the future, something to which American undergraduate students quite simply relate.

If, ultimately, this film has been successful in my classes, it is because of a pedagogical framework which, after preparation, permits a certain intellectualizing of its content: the noting of relationships and their organization into meaningful paradigms. This is certainly preferable to incomprehension and disinterest, but, it seems to me, students do not respond emotionally to the film, empathize with the characters - with the exception of a few scenes with Benoît - or recognize themselves in the characters' experiences. Again, not because the film is québécois, but because the director has probably not gone far enough in reducing cultural particularity to enable the foreign spectator full access to the ideas, the hopes and the passions of his characters.

\section{Pour la suite du monde}

Appearing in 1963, and marked as well by the preoccupations of the Quiet Revolution, Pour la suite du monde is a film which nonetheless appears to move beyond the restrictions of time and place (a small island in the St. Lawrence River, in the early sixties) to connect with spectators regardless of their cultural outlook. Cedric May, writing in a collection of essays on Quebec Cinema, in 1991, found that Perrault was able to 


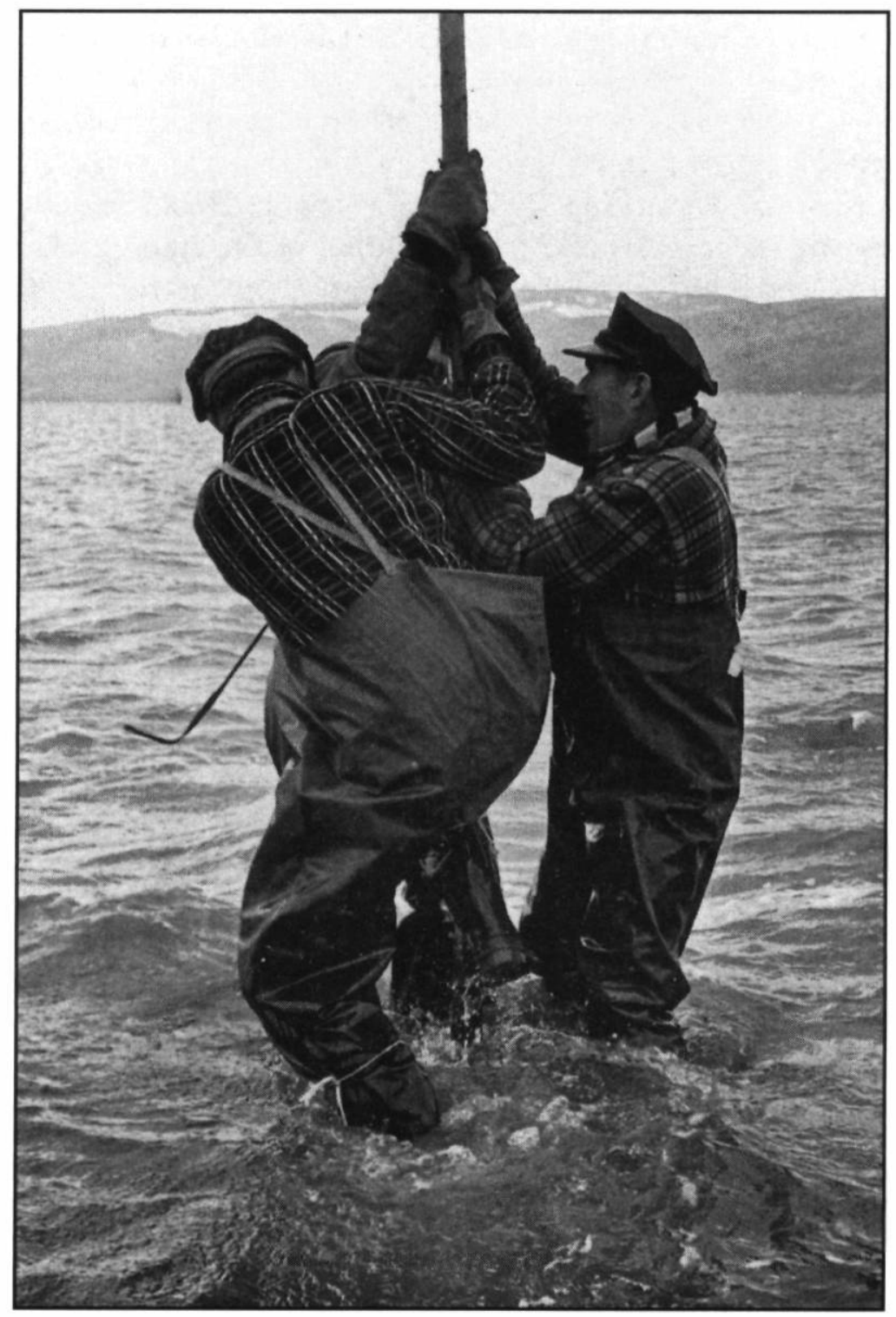

\section{Pour la suife du monde de Pierre Perrault (1963)}

Collection Cinémathèque québécoise

demonstrate in this unique example of direct film " [...] that memory survives best in the hands and muscles that performed

Teaching Quebec Film. Reflections of an American Academic 165 
for decades routine tasks, in the feel of the wind on the cheek of the sailor - essential to the navigator [...]" and in "[...] le beau plaisir, the joys and pains of community and shared toil." (p. 107) All of this seems to have remained, over the years, immediate and touching for students viewing Pour la suite $d u$ monde. But there is also the fascination of the ethnographer's project, the use of the actual inhabitants of the ille aux Coudres with their wonderful parlure, and the mesmerizing images of the construction of the "Moontrap" which contribute to its freshness. For all these reasons, both substantive and stylistic, students seem to conclude, the film speaks profoundly to the collective human experience and for that reason it speaks to them.

While they grasp easily that the film has mainly to do with the illumination "des traces" (Alexis Tremblay, sequence IV) or the preparation of "la suite du monde" (Louis Harvey, sequence VII), ${ }^{2} \mathrm{I}$ have in recent years been able to convince students that there are a certain number of elements in the film that appear at first extraneous to a meditation on the passing between generations of the fruits of ancestral invention and reflection. I am not speaking here of what François Baby refers to as "le deuxième sujet" sometimes found alongside the major theme in the typical Perrault's films. (p. 134) On the contrary, I believe that the approximate one-third of the sequences in Pour la suite $d u$ monde which sketch the various traditions and customs of life on the Island, like the mi-carême or the eau de Paques, only enhance the articulation of the primary theme of the necessary continuity of human experience from generation to generation. Sometimes, it is true, in unforeseen ways.

The first and most striking of the seemingly extraneous elements to which I refer above, stretches across sequences III and IV and deals respectively with Joachim Harvey's odd set-piece on the moon and, then, with a rather startling cameo performance by the moon itself. At first glance, the set piece on the moon, arbitrarily thrust by Joachim Harvey into the lively bidding for a rather coquettish ladies nightgown at the church auction (sequence II), appears so quaint that one suspects that it might have been slipped into the narrative by way of comic re- 
lief. The moon, M. Harvey informs a passerby - à propos of nothing whatsoever - has a great deal to do with earth, was in fact made for the earth, the proof being in the fact that the earth is inhabited and the moon is not. Were things the other way around, he concedes, it would mean the earth had been made for the moon. But this is not the case. In point of fact, he declares, little bits of the moon have been falling to earth over time and are responsible for the trees and animals and just about everything else we find here. The moon, he concludes, "c'est la nourriture de la terre." Although unseen interlocutors disagree with various of his propositions, Louis Harvey, seated beside him, is generally in agreement with respect to the purpose and importance of the moon. He does disagree (prophetically, as it turns out) with the notion that man will never travel there. He is on the other hand quite insistent as he repeats in various forms his strong conviction that "dans le fait de la nature, tout marche à la lune" and he concludes his remarks by announcing that "la lune est une affaire ben terrible."

No sooner has he made the latter pronouncement that the camera cuts to the darkened exterior of the church hall and we suddenly find ourselves confronted with a frame completely filled by an image of the full moon. Meanwhile, a male voice "off," backed by the murmur of the church auction, is explaining to us that the island has lived a charmed history, for, in the hundreds of years that its people have been crossing back and forth to the mainland, there has never been recorded a single boating accident. As the speaker makes his point, a second, smaller image of the full moon joins the first, which it will gradually replace in the unique, and, for that reason, arresting dissolve to be found in the film. In the mean time, the off screen voice continues in a self-congratulatory tone pointing out that no male inhabitant on the île aux Coudres has ever fought in a war (and though he does not say so, one guesses he might be thinking, "for the English!"). As the disembodied narrator pauses, the smaller full moon, alone now on an otherwise darkened screen, settles toward the horizon. All of this good fortune, the off screen voice continues, has come to the island because of the inhabitants' devotion to "nos petites âmes" (i. e., the souls 
in purgatory). A state of affairs he finds not at all surprising: where else than here, he asks, can you find people capable of raising $10,000 \$$ on a single occasion for masses for the souls in purgatory? One might suppose the question to be rhetorical, but as I like to point out to my students, there "is" a sort of response, for the full moon is now smiling mischievously on the murky waters of the Saint-Lawrence River - perhaps at the shaky theology of the islanders, or, at least, at the accountant's mindset, of the local faithful.

Students have suggested that the curious disquisition on the moon in sequence II could be a consequence of the "openness" of the producers' filmmaking process and of the liberty of expression it afforded to nonprofessional performers who, on this occasion, might have tossed off a bit of local nonsense/folklore, simply because it seemed to fit. This, I argue, is not a workable explanation, given that the verbal boutade is immediately reinforced, in sequence III, by the moon-centered movement of the camera : for better or for worse, it would appear, the film director is dans le coup. When one reflects further on it, moreover, this subtly satiric sequence, in which the presence and comportment of the moon appears to mock ever so gently the simple belief system of the islanders, is echoed in other parts of the film as well. Easter Water, one will recall from sequence XIV, is not obtained from the church after being blessed by the priest, as is the custom in France or, for that matter, in the neighboring United States. Rather, according to Louis Harvey, for the water to be efficacious, it must be drawn from a stream just before dawn, that is to say while earth still lies under the empire of the moon goddess and while the pure waters of the stream may yet reflect her image. One might, of course, go further and say that the Easter Water has been "blessed" by the moon. Elsewhere, it may be recalled, the dancing and general carousing of the masked townspeople at the mi-carême equally transpires in the night.

But there are, I have noticed over repeated viewings, other, more important, even decisive, instances of the moon's disturbing presence, which in the final analysis tend to refocus and to broaden significantly the meaning of the film. One of these is 
implicitly present in the ongoing discussion in the film of who originated the pêche aux marsouins: was it the French settlers from the North of France who had brought the expertise with them, or had it been devised long before by the indigenous Indians? All agree that whoever initiated the use of the elaborate trapping system, which the present islanders are seeking to replicate in the film, was possessed of genius, given the multiple variables of channels, tides and behaviors of the animal, which had to be taken into consideration. The simple matter of the choice of site for the erection of the trap was, they understood, crucial. Some, perhaps out of pride in the abilities of their forbearers, insisted that the method of trapping the white whale was the invention of the French immigrants. Others, among them Alexis Tremblay, attributed the creation of the first traps to the Indians. Finally, a book which he has had sent from the mainland, and from which he reads in sequence XVIII, appears to put an end to the controversy: according to the author, evidence of whale hunts carried out by the Indians had been noted by the first European settlers on the Island. But even without the book, I would argue, the film by its continual sly insistence on the significance of the moon has already made the case for Indian inventors of the hunt.

The moon, as everyone - including students - realizes, influences the rise and fall of the tides. From there, to a sufficiently accurate knowledge of the moon's ways to be able to predict where the six-meter tides will deposit a school of whales, so that when the tide withdraws the whales will be caught in the huge pole-enclosed trap, is a long way indeed. It is an especially long way for Europeans, whose ancestors had long ago, by dint of their advanced material civilization, lost, along with their sense of awed dependency, the intimate knowledge of the moon goddess and her ways. The North American Indian, on the other hand, who lacked the mind-glazing security of permanent habitations and European technology, and whose idea of civilization was based on the respect for, and knowledge of, nature, was constantly and closely in touch with what he knew as the "evening star. ${ }^{3}$ During the year, a succession of moons, often with appropriate names, presided over the vital activities (hunting, 
fishing, migration) upon which his survival depended, while his wife calculated her menstrual cycle after the phases of the moon. There can be little doubt, given his reverence for the beneficent moon goddess, whom he considered the consort of the sun, and his precise knowledge of her power to influence the conditions of life on earth, that long before the coming of the Europeans he had solved the enigma of the tides and perfected the idea of the "moontrap." 4

More or less oblique references continue to be made to the moon and its sphere of influence, right down to the final sequences of the film. In sequence XXII, labeled "Les âmes et les marguerites," while one of the islanders regrets having paid in advance "les âmes," who have shown themselves remiss in not delivering whales into the trap, the alert spectator, recalling the earlier moonlit satire of the local religious mindset, can only smile. When shortly thereafter, the high tide delivers the longawaited beluga whale into the trap, the same spectator will have few illusions about how this miracle has been brought about.

Significantly, the very last sequence of the film, entitled simply "Lune," confirms once again the perspective on the moon's influence on the fortunes of men, which has already been set forth, albeit discreetly, at various earlier moments in the film. When still another islander complains about the neglect of les ames, given the fact that the great trapping adventure has resulted in the catch of only one marsouin, Louis Harvey mildly taunts him with the idea that he and his colleagues of the hunt have made the mistake of paying insufficient attention to the moon!

What characterizes belief systems is that they exist outside of reason and logic and their apparent successes in relation to a particular human community are unrelated to anyone's ability to demonstrate that one system is more likely than another to embody the Truth. From this perspective, the apparently mindless talk in sequence II, alleging the singular importance of the moon to earth and to human beings, seems, ironically, to be as sensible as the discussions of the commerce, widely held to go on between the "petites âmes" and the island inhabitants, whereby the former protect the latter in exchange for money 
paid to the priest for masses designed to abbreviate their stay in purgatory. In fact, the truth be told, those holding the moon in reverence might have an even stronger case than the proponents of the "petites âmes," since the influence of the moon on the tides is something that can be verified empirically. In the final analysis, the human continuity prized both by the filmmaker and the characters in his film may extend beyond the generations of Quebecers or even the Indians who made their home on the ile aux Coudres; perhaps what the film is really telling us is that the nature-centered belief systems imbedded in the psyche of prehistoric man have never really been surpassed, nor are they likely to be. Such a point of view, it seems to me, locates Perrault in advance of other thinkers and artists of the Quiet Revolution, in that his reverence for continuity and his concern for a québécois identity, in 1963, do not preclude a skeptic's appraisal of traditional religious views.

In sum, this is a film capable of mesmerizing not only American college students, but anyone, anywhere, in part, because it does not allow its socio-political preoccupations to stand in the way of its depiction of the wonder, the fears, the solidarity and, above all, the persistence to endure of all participants in the human adventure.

\section{Sonatine}

Of the various québécois films I have worked with over the years, Micheline Lanctôt's second feature film, Sonatine is the film that seems to relate most directly to the sentimental and intellectual experience of my students. And unlike the less demanding popular films coming out of Quebec, Sonatine is successful in spite of a problematic musical structure, dark tonalities, and a carefully made soundtrack with relatively little dialogue, all qualities that establish its links both to the indigenous documentary tradition and to European auteur theory.

In the film, Lanctôt focuses on the lives of two adolescent girls, Chantal and Louisette, as they struggle, virtually unaided, in a universally recognizable space, that of the transition from childhood to the still alien world of adults. True to the promise of its musical title, this coming of age film unfolds in a three 
movement sonata structure equivalent to I: Chantal; II : Louisette; III : Chantal/Louisette and coda.

The first movement, which occupies about one third of the film, concerns itself with the ritual bus rides of Chantal who everyday, for days on end, arranges to get the same bus, at the same time, in order to spend a few minutes with the same bus driver, with whom she believes she has fallen in love. Day after day, with an intensity and single-mindedness given perhaps only to adolescents, she drinks in the sight of her hero, while recording his most banal propos on her omnipresent "Walkman," for later play back and fantasizing. A chance remark in which he refers to her as a child causes her to bristle with indignation; but on another occasion, he mentions how pretty she looks, and she quivers with pleasure, replaying his comment over and over on the Walkman, even before leaving the bus. Meanwhile, the bus driver, unaware of the adoration he has inspired, contends with his own adult problems: management that threatens his job if he can't run a tighter schedule, colleagues who harass him because he is unwilling to share their strike plans, a scolding wife angry at him apparently on principle. One day, for one or all of these reasons, her bus driver does not reappear, and Chantal is obliged quite abruptly to abandon her life-enriching fantasy. Her shock and pain upon discovering the replacement driver are palpable.

In part II, Louisette, whom we have seen only briefly, under the credits, as the two listen to an audio tape, reappears in a parallel segment of about equal length to the first. Leaving her home one evening in stealth, without explanation, she travels to the Port of Montreal, where mysterious lights and activity punctuate occasionally the darkness. Choosing a rusty old hulk of a freighter, Louisette sneaks aboard with the possible intention of stowing away. What follows is a remarkable, chiaroscuro sequence, clearly an hommage to Antonioni's Deserto Rosso (Antonioni, 1964), which suggests a strong parallel between Louisette and the Monica Vitti character of the earlier film. When her presence on the ship is discovered by an angry Russian sailor, the fear and unhappiness on her young face are sufficient to give him pause. Soon he is chatting pleasantly with her in a lan- 
guage she totally ignores. As in Red Desert, the alienated state of the young woman is poignantly illuminated by her greedy response to a human contact, which comes through in spite of the formidable barrier of language. She offers him some of her chocolate; they exchange jackets and hats; she laughs for the first time as he mimics comically her stealthy arrival on board. For Louisette, a lover of all things Russian, the moment is exquisite but short lived. With the return of other crew members and preparations for departure, she is soon obliged to go ashore, turning her steps once more in the direction of the empty city. He gives her a half-empty packet of cigarettes and voices the hope that he might return one day to Montreal to see her. Sirens shrill in the background and flames leap from a vandalized bus, victim of labor unrest - one of the prices to be paid for the new prosperity - as Louisette leaves the port.

In the third major segment of Sonatine, Chantal and Louisette are continuously together, that is to say, together alone. Each one is the only child of a middle-class, two-income family, and has little contact with parents whose time is taken up with jobs, supplementary classes, and the desire to better their already agreeable material situation. A short sequence in the metro sums up poignantly the child-parent relationships as Louisette waves repeatedly to her transit worker father at the controls of a sleek subway train, which speeds abruptly into the darkness before he is able to notice her. Once aboard their own train, the girls write their phone numbers on the sparkling clean wall; perhaps someone, anyone, will call.

The school environment echoes that of the home, a clean, modern building awash in computers, special rooms and services; but nothing or no one apparently is up to the task of getting behind the adolescent mask of sufficiency in order to make Louisette or Chantal feel loved or important. Teachers are invisible except, significantly, in a scene reminiscent of Truffaut's Les Quatre Cents Coups (Truffaut, 1959), in which Chantal is taken to task, in the presence of her parents, for a recording she has brought to school; its content is not revealed, but the looks on the faces of the parents suggest that it might be something on the order of a family quarrel - or perhaps the opposite. 
Shortly thereafter, the girls leave a computer session to pillage the pointedly unattended but beautifully equipped school infirmary. Giggling all the while, as if engaged in a childish prank, they succeed in making off with a large quantity of assorted pills. At home, Chantal dashes off a short poem about an oyster "caught" in a poisonous sea, which closes its shell definitively and is in time cast up on the shore. Eventually, after some discussion of possible sites, they go to the metro, where they set themselves up in a train car under a homemade sign that informs the "indifferent world" that they will swallow pills until someone intervenes to stop them. Student viewers invariably gasp, as subway passengers, caught up in their own concerns, pay no attention to the girls who, still whispering gaily, wash down pill after pill with gulps of milk from a cardboard container. They fall asleep just as the train glides into its terminal. Waking passengers quickly leave, but before the conductor is able to carry out his check of the cars he learns that a longawaited train strike (a second allusion to the price of material progress) is set to begin immediately. At that, he cuts the electricity and quits the train, leaving the unsuspected/unsuspecting pair to their fate. Although no one has overtly wished them harm, the youngsters evidently will not survive their lark.

Sonatine is characterized by a strongly ironic structure, wherein two sensitive adolescents perish for want of moral sustenance in the midst of the unparalleled material prosperity of the new Quebec. Instrumental in defining the relation between new affluence and the alienated teenagers, are the ever present, upscale "Walkmans," which, in this case, can record sound as well as play audio cassettes. In addition, therefore, to the variable volume control, which allows them more or less to distance the world, Chantal and Louisette are able, by the selective recording of their environment, to reinforce the fragmented grasp of things implicit in their passionately incomplete vision, and thereby to strangle at its inception any impulse to lifepromoting dialogue with the outside. But, it might be argued, an even more haunting image of their tragically ironic experience may be found in the glittering, sleek subway train - the triumph of Mayor Drapeau and Bombardier - which, filled 
with indifferent passengers, nonchalantly whisks the friends to their death in the darkened vaults beneath the city.

While there are certainly things to be said about the evocation in Sonatine of the ambivalence of modern Quebec to the momentous changes of the preceding decades, what strikes the viewer - my students included - above all, is the simple, incredibly sensitive depiction of adolescent friends incapable of making, alone, the transition from the dreams of childhood to the gritty and sometimes repugnant reality of our adult world.

My observations based on years of watching and thinking about Quebec films and the reactions of my students to some of the films I admire are in no way intended to be a rigorous examination of the problem of the viability of Quebec cinema in the United States or elsewhere. It is in fact obvious, I think, that I enjoy more talking about the structure and meaning of films than about the difficulties American undergraduate students might have in addressing them. Still, because the matter of exportability is vital for any national cinema (especially those of smaller countries) and because American students share with other non québécois viewers a cultural ignorance of Quebec, there may be something to learn from their experiences as I have reported them here.

Generally speaking, the cultural baggage of a filmmaker is never divisible from his directorial vision. His nationality, his culture, his language, among others, are part and parcel of his creativity. This truth explains Truffaut's reluctance to make a film in English in the United States; it also explains the failure of Antonioni's Zabriski Point (1970). A Quebecer who makes films, has no choice but to make Quebec films, and that is as it should be. There can be no question of a Quebec director altering what is "essentially" québécois in his work in order to capture a larger world audience, for to do so would most certainly undermine his ability to create anything of value. As Denys Arcand has put it: "Les films de Bergman sont suédois; les films de Truffaut sont français; les films de Spielberg sont américains. Ainsi, les films qui marquent durablement le cinéma mondial sont des films intensément nationaux." (quoted in Abel, p. 114) On the other hand, and this is perhaps the lesson to be drawn 
from my experience with American undergraduates, it is possible to conserve one's national creative identity while keeping the outer, idiosyncratic trappings of a film to a minimum. For people who know Sweden and Swedish culture, the films of Bergman are full of it, but it rarely gets in the way of a spectator who is, for all practical purposes, ignorant of things Swedish. What is true, moreover for Bergman is also true of Fellini or Bunuel, or for a host of others. Denys Arcand has also said that if Quebec films have not seriously impacted the world market it is not because of bad distribution or other extrinsic considerations, "c'est parce qu'ils n'étaient pas assez bons," (p. 114), and he is of course largely right. But while there is no substitute for directorial skill and vision in creating a world class film, it is also true that the cultural ties of the filmmaker must not be allowed to obscure the quality of a film thereby rendering it inaccessible or unpalatable to spectators from another corner of the world. The relative international success of Jésus de Montréal (1989), deeply québécois in conception but universally accessible to spectators (including my undergraduate classes), demonstrates that Mr. Arcand is equally aware of this fact.

\section{Michigan State University}

\section{NOTES}

1 See Robert Crawford, "Mon Oncle Antoine: Cinematic Analysis of a Quebec Masterpiece," Symposium on the Modern Quebec Film, East Lansing, 7-8 April 1989.

2 For the division of the film into numbered sequences, see François Baby's paper "Pierre Perrault et la civilisation orale traditionnelle," in Pierre Véronneau, Michel Dorland and Seth Feldman (ed.), Dialogue. Cinéma canadien et québécois. Canadian and Quebec Cinema (Montréal : Mediatexte Publications Inc. I Cinémathèque québécoise, 1987, p. 123-138).

3 For a general treatment of the beliefs and customs of North American Indians, see The World of the American Indians (Washington: National Geographics Publications, 1974).

4 While the origin or etymology of the word " moontrap" is unknown to me, the fact that it is used as the English title of the film suggests someone's implicit recognition of the importance of the role of the moon in Pour la suite du monde.

5 A portion of following discussion of Sonatine has been adapted from my earlier essay, "Sonatine in Context, a Neglected Film of Micheline Lanctôt," Essays on Quebec Cinema (East Lansing: Michigan State University Press, 1991, p. 157-167). 


\section{WORKS CITED}

Abel, Marie-Christine, André Giguère et Luc Perreault (ed.). Le Cinéma québécois à l'heure internationale. Montreal : Alain Stanké, 1990.

Baby, François. "Pierre Perrault et la civilisation orale traditionnelle," in Pierre Véronneau, Michel Dorland and Seth Feldman (ed.), Dialogue. Cinéma canadien et québécois. Canadian and Quebec Cinema (Montreal: Mediatexte Publications Inc. I Cinémathèque québécoise (1987), p. 123-138.

May, Cedric. "Pierre Perrault and the Quebec Documentary: for the continuity of Humanity, " in Joseph I. Donohoe, Jr. (ed.), Essays on Quebec Cinema. East Lansing: Michigan State University Press (1991), p. 103-110. 